\title{
Religion in a private igloo? A critical dialogue with Richard Rorty
}

\author{
Hartmut von Sass
}

Received: 10 December 2010 / Accepted: 3 February 2011 / Published online: 26 February 2011 (C) Springer Science+Business Media B.V. 2011

\begin{abstract}
It is still a popular philosophical position to call for a strict "separationism" concerning the private and the public sphere when it comes to religious convictions. Richard Rorty is one prominent supporter of this claim. The traditional critique against this division is mostly built on a particular characterization of religion that is at odds with Rortian assumptions. In this article, however, Rorty is criticized on his own terms turning pragmatically the objection to a fully internal one. What Rorty values most, namely a tolerant and ironic liberalism as the capacity to describe oneself in new and interesting ways is precisely the role, I argue, that religious faith could play under "neo-liberal" conditions.
\end{abstract}

Keywords Rorty · Irony · (Neo)liberalism • Privacy · Public sphere · Metaphysics · (Self)understanding

\section{Introduction}

Few people would still claim that religion's social place should be one of complete privacy. But there are indeed many claiming that religion's epistemic grounds are defined by private structures only. The first claim is a normative call for an ultimate restriction of religion due to the ramified difficulties of living within a pluralistic society. The second claim is a descriptively achieved conclusion focused either on religious practices or on the very grammar of the faith that citizens actually practice. Both claims are under pressure although the second has gained a bit more sympathy, especially from Lutheran theologians (of a certain kind) underlining the 'inwardness of faith' or the 'inner impression' of Jesus as (moral) example. I am thinking here of some pietistic and

H. von Sass $(\varangle)$

University of Zurich, Kirchgasse 9, Theologische Fakultät, 8001 Zürich, Switzerland

e-mail: hartmutvonsass@access.uzh.ch 
liberal writers with very particular (and 'particular' means: single-minded) readings of the early Schleiermacher. The majority of theologians, however, has criticized this strand of thought, emphasizing that religion is part of our social interaction or as Paul Tillich put it, that Christianity belongs to the "substance of culture". ${ }^{1}$ If one denies the second descriptive claim (that religion is essentially private), the first normative claim (that religion is to be limited to the private sector) is intelligible which would mean: religion should be private, because it is not private per se.

One of the most prominent supporters of this latter claim-oscillating in a problematic manner between description and normativity — is Richard Rorty (1931-2007). What others consider to be completely confused, namely to banish faith as publically excised act to the 'private igloo', is exactly what Rorty is eagerly interested in achieving-for very different reasons and with a specific understanding of 'privacy' that is particularly inspired by John Stuart Mill. The author of the famous On Liberty argues strictly for a separation between the private and the public, taking these spheres to be the realms of personal freedom and legal regulation, respectively. One could maintain that the Millian liberalism is nothing but a strong juxtaposition of both conflicting sectors celebrating the value of the private domain and accepting the practical necessity of the public constrains. ${ }^{2}$ In this sense Rorty is Mill's inheritor.

The goal of my article is, first, to understand better Rorty's background assumptions for his critical claim; second to outline the context, in which he deals with religion, i.e. his picture of a liberal and ironic society governed by tolerance, the foremost enemy of which is allegedly religious orthodoxy in any stripes; and finally, to contemplate the possibility, pace Rorty, that at least the Christian tradition is not only one important source of Rorty's own irony, but also an essential amplifier for the core activity in which ironic liberals should be engaged: finding new descriptions for our understandings of public and private selves. This leads to a kind of criticism that sticks to Rorty's own conditions, turning the critique to a fully internal one without signing up something that the neo-Millian liberal would refute. Speaking non-metaphorically my thesis is that what Rorty values most-private freedom and publically secured tolerance-is not threatened by religion but deepened because religion is a specific mode of living in new possibilities. Speaking metaphorically my thesis is that the temperature in religion's private igloo increases constantly, the igloo melts destabilizing the icy wall between it and the public, eventually breaking down altogether.

\section{On separating the private and the public}

Rorty's separation between the private and the public sphere is not primarily concerned with religion or religious movements and their eventually negative influence. Rather, this bivalent interpretative structure pervades Rorty's whole thinking, at least his post-analytic period (earlier, he had not been interested in these kinds of debates at all). In other words, religion - in a very broad and unspecific sense-is not more than one of many important instantiations of an ideally private business that can interfere in

\footnotetext{
1 Cf. Tillich (1975, p. 84).

2 For John Stuart Mill's liberalism see Rössler (2007, esp. pp. 60-61).
} 
disturbing ways with social, public and political interests; other examples of a similar kind may be sports, arts, or certain political, sexual and even other moral ways of orientation that belong strictly to the private sector.

Rorty biggest fear is that religion could smuggle private interests into the sphere of publicity. As far as I can see, he does not argue positively for the separation needed so urgently, but solely by referring to the negative consequences that such a smuggling in would entail (cf. PC, 35, 37). ${ }^{3}$ Whatever these 'consequences' may be in detail, traditionally, the thesis toward which Rorty is inclined can be presented in two versions: The empathetic one maintains that it is for religion's own sake to remain private, whereas the second one calls critically for restricting religious ambitions in times of cultural clashes. The fact that Rorty underlines the 'negative consequences' makes it clear that he prefers the latter reading. ${ }^{4}$

His reaction is, to put it briefly, to privatize religion. Adopting arguments from Mill and William James he promotes the "Jeffersonian compromise" that is built on the traditional idea that "the secularization of public life is the Enlightenment's central achievement". 5 Although Rorty will criticize the basic reasons James put forward for defending the "compromise" he still defends the conclusion "keeping [religion] out of [...] 'the public square', making it seem bad taste to bring religion into discussion of public policy" (SH, 169). Rorty's own reason in favor of the "compromise" (as the best of different bad options) is still very simple; he states:

The main reason religion needs to be privatized is that, in political discussion with those outside the relevant religious community, it is a conversation-stopper. ${ }^{6}$

Thus, the separation between the private and the public is, according to Rorty, one of the most important distinctions we have to draw and to save (cf. PZ, 120). The private is the sphere of "self-creation" and "self-perfection"-a room in which it is allowed and possible to find to oneself even by idiosyncratic ways, means and detours. Privacy is here (and in Mill's case too) focused on or even reduced to freedom and freedom is understood as individual freedom without recognizing that the private goes beyond negative civil rights. ${ }^{7}$ The public is not confined on achieving something 'good', but on avoiding the varieties of its opposite; it has neither an intrinsic, nor a contingent

\footnotetext{
3 I will use abbreviations for Rorty's publications; see references.

${ }^{4}$ Unfortunately, Rorty is hardly interested in the historical background(s) of the debate over the statechurch-separation or, more generally, the allegedly clear cut between privacy and publicity. Charles Taylor, however, reminds us of the twofold task the separation had to fulfill: not only to protect the state against religious infiltration, but also to protect the personal religion against the dominance of the Great Awakening in relation to other religious orientations; see Taylor (2002, p. 19).

5 Rorty, "Religion As Conversation-stopper" [1994], in SH (169 \& 168), and TP (42 \& 44).

6 Ibid., p. 171. One might ask which religion Rorty has in mind: the Lutheran church in Europe or the southern Baptists in Alabama or the growing Catholicism in Latin America? Rorty-as reader of Hegel-has no notion that religion is one of the places where people give themselves a definition of truth and 'negotiate' what is relevant and important for them (see Hegel 1955, p. 125); and they will do so in very different ways as they live under highly different circumstances. Nevertheless, one should not forget that Rorty writes as an American who might have in mind a rigorous fundamentalism that does exist in central Europe as well but not as a representative religious element.

7 See Rössler (2007, pp. 148-150).
} 
positive and material ideal. The public is only formally built upon the fight against cruelty and the realization of tolerance for mankind and its solidarity. ${ }^{8}$

Rorty's interest in personal freedom, which is based on a tolerant society that fights against human cruelty, is near to be taken for granted, which might be the first step to losing it. What leads notoriously to criticism, however, is that Rorty maintains both spheres to be incommensurable. "Projects of individual self-expression" on the one hand and "projects of social cooperation" on the other (PC, 35) rule each other out although (or because) they are equivalent in terms of value and legitimacy (cf. CIS, xiv). ${ }^{9}$ One could argue that Rorty's famous book from 1989 Contingency, Irony and Solidarity was initially written to describe what happens when self-creation (by philosophy and literature) remains private without being compounded with the opposite sphere of the public.

Now, even Jürgen Habermas - and in opposition to Rorty_in his late years came to the conclusion that religion should play a major role in and for society. Therefore, he leaves the old picture according to which the conflict is to be solved not by weakening the religious claims but just by restricting their practical impact. Going beyond this approach Habermas presents two considerations that could be interesting for the Rortian ideal of a "conversation of mankind". First, Habermas holds that religion encompasses resources of meaning, sense and significance that are (to some extent) translatable into a vocabulary that is accessible even for those who are "outside the relevant religious community" (Rorty; see above). ${ }^{10}$ Second, the post-Enlightenment Christianity has amplified the culture of discourse by strengthening the awareness of the historical fact that we live in a "post-secular" and plural society; Schleiermacher has played an important role for incorporating this new sensibility. ${ }^{11}$ Both aspects lead to a possibility that is noted nowhere in Rorty's œuvre, namely that society is not only to be saved against inacceptable religious fundamentalists but also to be protected against the danger of retiring into private life, i.e. the retreat into an indifference that undermines every vivid public culture of debate.

Unfortunately, Rorty does not elucidate the relation between the private and the public sphere apart from maintaining their separation; but even this claim is far from precise. The main obstacle for clarification lies in neglecting important distinctions such as between legal and civic (political), divine and secular (theological), religious and secular (institutional) or religious in one sense and religious in another (interreligious). Either Rorty thinks his public/private-bivalence does the job of all these pairs

\footnotetext{
${ }^{8}$ Cf. Conant (2000, esp. pp. 283-291).

9 See PZ, 118-119, where Rorty underlines the importance of finding the right balance between 'originality' and 'tolerance'.

10 Habermas (2005a, esp. pp. 134-137). One could ask whether the translation is an interreligious enterprise (translating a particular vocabulary into another religious vocabulary) or whether the translation means the transfer into a non-religious language. The latter claim has some resemblance with Ernst Fuchs' and Dietrich Bonhoeffer's claim that Christianity in an atheist era has to speak in non-religious terms-etsi Deus non daretur.

11 Habermas says (2005b, p. 251):
}

„Schleiermacher ist ein Schrittmacher für das Bewusstsein einer postsäkularen Gesellschaft, die sich auf das Fortbestehen der Religion in einer sich fortwährend säkularisierenden Umgebung einstellt.“ 
or he shows no real interest in these ramifications. ${ }^{12}$ In particular, he does not elucidate by which notion the contrast to 'privacy' is constituted. If it is the political stage then privatizing religion just means that religious movements, sects or confessions are not allowed to interfere politically. It is, of course, something different as soon as we speak of the public as cultural publicity. In this regard privatizing religion would express a much stronger claim itself near to be intolerant. Rorty, however, does not distinguish between these divergent notions of the public and, accordingly, he cannot admit that privatizing religion in the political sense is widely accepted precisely because one wants to allow for not privatizing religion in the cultural sense (see above: the 'empathetic reading').

Although Rorty thinks both spheres to be theoretically or principally equivalent, making him call for finding the right balance between them (actually finding it is, for Rorty, a kind of "wisdom"; cf. PZ, 118), it is not clear whether both spheres are practically equivalent when we face conflicts between private hopes and social needs - the type of conflicts that cause Rorty's claim in the first place. Hence, one might ask whether Rorty presents a conditional equivalence that is to be substituted by the pragmatic priority of the public (or the private) if necessary. But if this priority were so easily sustained, then we would have no real problem with the separation hoped for; in other words, the fact that the public's (or private's) priority is questioned often enough is not a threat to an accomplished solution, but one facet of the initial problem.

What is clear, however, is that Rorty defends a strict 'separationism'13 as a response to the storm of consequences we have to deal with in rejecting his position-a position he presents as non-metaphysical. To put it the other way round: He criticizes all approaches of combining the private and the public as metaphysical enterprises; metaphysics is, according to Rorty, nothing but the project of creating one single vocabulary encompassing both sectors (cf. CIS, 120). Ironically, Rorty confronts us (and himself) with the impoverished option between a metaphysical monism regarding the one vocabulary for the public and the private on the one hand and on the other hand the non- or post-metaphysical dualism consisting of two vocabularies, one for our self-creation and, one for our social interactions. Traditionally, dualisms belong to the metaphysical inheritance-so, what we get from Rorty is a very extravagant mixture of a non-metaphysical metaphysics (see below).

This very mixture is the background for criticizing some of his most admired heroes for not having paid attention to this basic demarcation. Heidegger and Derrida are presented as great 'private', but blind 'public' philosophers [whereas Rorty says the contrary concerning authors like John Rawls and Habermas (cf. PZ, 26 \& 29)]. According to Rorty's reading, Heidegger considers himself to be post-metaphysical (not: anti-metaphysical) while simultaneously attempting implicitly to create a single vocabulary for both spheres. The result, not this intention, makes Heidegger one of the greatest philosophical reformer of language (cf. CIS, 112-115; PC, 170).

\footnotetext{
12 Connected to this problem is another: which kind of non-private organization is the addressee of Rorty's concern. Sometimes his criticism is focused on an anticlericalism; see esp. PS. Then, we had to deal with an institutional challenge which begs the question: how to handle organizations under the institutional level?

13 See for this term Amesbury (2008, p. 205).
} 
In finding and inventing this language Heidegger faces two major problems. Number one: How to write on and rewrite the development of metaphysical projects without turning out to be a metaphysician (cf. CIS, 108)? Number two: How to write on and rewrite without losing the audience, i.e. avoiding writing 'only' on a private basis, not for public purposes? The first problem of self-application is circumvented in Heidegger's later philosophy by presenting de facto his vocabulary as both the result of his search for the 'right' word and as only one provisional step within this search; his vocabulary is a self-demolishing language without lamenting over this ongoing process (cf. CIS, 117-118). ${ }^{14}$ The second problem of representing the public audience leads, for Rorty, to the outlined confusion. Heidegger's ambition to speak not only for himself but to speak (in the mode of invitation) in the name of others separates him from more cautious writers coming from literature. Marcel Proust is Rorty's main counterexample for confining what one writes to the private sector without any further ambitions (CIS, 118). ${ }^{15}$ But Heidegger's implicit search for the 'last, final and closed vocabulary' is doomed to fail (cf. PZ, 67 \& CIS, 96), because the claim to speak for others is hardly justified and the hope to speak for others is often enough disappointed.

Therefore, Rorty confronts us with an unhappy alternative: either sticking to metaphysical enterprises or separating private religion from the public sphere. But in complaining about certain vocabularies Rorty himself uses, of course, a particular terminology in publishing his (private-?) concern for the sake of the public. For this purpose, he chooses a way that is dominated by spatial metaphors: He speaks of "spheres" of privacy and the public, he speaks of "sectors" presupposing clear cuts and a bivalence of only two "domains" or "squares". This move does not come without a price and leaves room for alternatives, i.e. alternative metaphors. Accordingly, I will argue for turning Rorty's fideistic (or solipsistic) either/or between monist metaphysics and strictly dualist separation into a neither/nor by looking at the various ways in which religious practices transcend private inwardness and demand socially relevant publicity — then, the igloo will begin to melt.

\section{Liberal ironists}

Before exposing this neither/nor, we have to understand Rorty's either/or. The main figure representing this choice is the liberal ironist who embodies the separation between the private and the public. Her most important character traits are described by Rorty as follows:

I use 'ironist' to name the sort of person who faces up to the contingency of his or her own most central beliefs and desires - someone sufficiently historicist and nominalist to have abandoned the idea that those central beliefs and desires refer back to something beyond the reach of time and chance. Liberal ironists are people who include among these ungroundable desires their own

\footnotetext{
14 See, for instance, Heidegger (1959).

15 Another, philosophical, example is Nietzsche who gave up the idea to understand others and himself in only one single vocabulary (which is, obviously, something different than to say, as Rorty seems to do, that these vocabularies correspond to the both spheres of the public and the private; cf. CIS, xvi).
} 
hope that suffering will be diminished, that the humiliation of human beings by other human beings may cease. [L]iberals are people who think that cruelty is the worst thing we do. ${ }^{16}$

The major virtue of the liberal ironist is tolerance (cf. PZ, 180) secured by regarding theories, vocabularies, novels, even religious practices as tools for private self-creation or edification (cf. CIS, 96), none of which has an intended impact on the public sector. More precisely, ironic self-creation or edification does not necessarily contribute to Rorty's picture of a society that is governed by solidarity and tolerance (cf. CIS, 99-100). "Why not?", one might ask, especially under Rorty's own conditions (I will come back to this point).

The main task the liberal ironist (or the ironic liberal) has to fulfill (or: the task that makes someone ironic and liberal in the first place) is self-creation (i) by finding new description (ii) using literature turning 'self-creation' into the 'creation of the self' (iii). I will try briefly to elucidate these three elements:

(i) The term "self-creation" is a Nietzschean one that substitutes God with the human will and its ruthless or compassionate force as the 'source of the self'; the object remains creation's object by becoming its subject. ${ }^{17}$ 'Creation' does not mean that you change your corporeal appearance; beautifying surgeries are not necessarily Nietzschean enterprises! What is meant is to understand oneself in new and interesting ways - ways that indirectly but forcefully change oneself by altering the pictures, narratives and attributes of this self. There is at least a threat of relativism, but the hermeneutical process of this kind of self-understanding is not relativistic by necessity.

Relativism should not be confused with contingency, and to deny the former does not exclude the latter; that something is not relative does not imply, of course, that it is without alternatives; it might be contingent which means that there are reasons (pace relativism) but that they are not sufficient in terms of determining something necessarily (pace what Rorty calls metaphysics). The 'contingency of language' is Rorty's main reference point insofar as language as tool of our self-understanding is not arbitrary, on the one hand, but is not fixed as the 'adequate' description by reality on the other. Reality (or the 'world', as Rorty sometimes says) does not decide between different vocabularies as 'right' or 'wrong' insofar as Rorty has abandoned the Platonist view that language as such represents or "mirrors" the world (cf. CIS, 5$6,20-21,99)$. This abandonment is at the heart of the disenchantment of the world ${ }^{18}$;

\footnotetext{
16 Rorty, CIS, xv (the last sentence stands in front of the rest of the quotation in the original); see also PZ, 48, 170, 179.

17 Another metaphor besides ,self-creation' is 'self-enlargement'; see PZ, 7.

18 Or as Rorty says once:
}

\footnotetext{
If we cease to attempt to make sense of the idea of such a nonhuman language, we shall not be tempted to confuse the platitude that the world may cause us to be justified in believing a sentence true with the claim that the world splits itself up, on its own initiative, into sentence-shaped chunks called 'facts'.

To say that truth is not out there is simply to say that where there are no sentences there is no truth, that sentences are elements of human languages, and that human languages are human creations. (CIS, 5; the order of both sentences is the other way round in the original).
} 
the reverse, however, consists in promoting the self to find coherent self-descriptions on his own turning the so called self-perfection into a matter of private business (cf. PC, $41 \& 31$ ).

(ii) Accordingly, Rorty's trust in the force of language is eminent. Changing the ways of describing oneself changes the self at the same time. Hence, the self is considered to be an entity embedded in descriptions. ${ }^{19}$ The plural-'descriptions-is important because the self could be characterized in many ways that might be incommensurable: as autonomous person, as sinner, as legal addressee, etc. ${ }^{20}$ The ironist does not try to reduce them but has the strength not only to deal with these different voices, but to 'celebrate' them. Moreover, she is up to the task of finding even new descriptions that might 'fit' 'better' her self-understanding. Both terms- 'fit' and 'better'-are ambiguous: 'fit' does not mean that there is any standard 'out there' defining the fitting, but the other way round: that new descriptions 'emerge' with their own plausibility; and 'better' does not mean coming nearer to reality, but the other way round: that new description touch our sense for what reality could possibly mean (cf. CIS, 12, 16). Accordingly, the force of language does not consist in mirroring exactly but in imagining creatively (cf. PMN, 382).

(iii) The central tool to achieve this self-creation is literature. Novels, in particular, contribute to the recognition of the variety of life orientations, styles and preferences that might be alien to other persons. Being confronted by Hans Castorp, The Count Myshkin, Ulrich 'the man without features' or the cosmos of La recherche du temps perdu widens our moral sense and gives access to the contingency of our own convictions, beliefs and commitments (although there are very different possibilities of responses besides the enlargement of the moral sense-possibilities, like alienation, Rorty has not in focus here; cf. R, 57). Although Rorty concentrates on discussing novels he leaves room for other media such as biographies or the cinema as 'tools' (one of Rorty's favorite metaphors in line with pragmatist thinking) for self-creation understood as self-understanding.

Apart from this concession Rorty remains focused on literature, ${ }^{21}$ which is also, in a way, revealing of his attitude towards religion. This attitude is developed in (at least) three steps. Step one deals with philosophers like authors of fictive literature: "literally orientated intellectuals", as he puts it, among them are: Kierkegaard, Nietzsche and Heidegger (cf. PZ, 56-57), for whom the border between literature and philosophy breaks down. Step two: Rorty thinks that philosophy has taken over the legacy of religion, namely its salvific and reconciling force; the vanishing role of religious confessions in the public does not entail the disappearance of the private need to be redeemed; philosophy has now the task to fulfill this desire. Step three: Nowadays, philosophy is itself in the course of being replaced be literature (step one \& two). The hope of reconciliation and redemption [whatever that could mean in Rorty's (post)secular

\footnotetext{
19 See Schapp (1953).

20 Rorty celebrates Spinoza as the first 'postmodern' philosopher for allowing different incommensurable descriptions referring to one single referent; cf. PZ, 105, 114 and TP, 16.

21 One important source for Rorty is Harold Bloom's work on literature and his literature theory saying that the act of reading is a process to become an autonomous self in the Heideggerian sense of 'authenticity' (Eigentlichkeit); cf. R, 49, 53.
} 
world $^{22}$ is comparatively stable, whereas the media of their realization change. This last step is only partly presented in the indicative mood, but is rather an imperative to run through a history of substitutions from religion via philosophy to literature (cf. PC, 91-95; R 53; PZ, 185-186). ${ }^{23}$ We live now in the period of literature. What comes next? ${ }^{24}$

What we have here is Rorty's thesis of secularization which he does not present at a descriptive level but in hope of speeding up this process. Insofar as he takes the Enlightenment's crucial achievement to be the secularization of the world-a world not yet fully realized today-we have to strengthen the "Jeffersonian compromise" by being more critical of the past and more open to new experiments in the future (cf. $\mathrm{SH}, 168-169)$. It is no surprise that Rorty considers himself and the left liberal wing to which he belongs to be an important amplifier of this process. ${ }^{25}$

What has all this to do with the strict separation as the Rortian dualism of spheres? The threefold line of thought I outlined from self-creation (i) via searching for new descriptions (ii) to the usage of literature as the contemporary tool of redemption (iii) shows how difficult — not to say, impossible - it is to draw even heuristically the line between the private and the public. 'Irony' seems to be a private endeavor, namely the ability to play ironically with the contingent plurality of very different vocabularies; 'liberal' is by definition a political and social term leading into the public (dis)order. What then could an "ironist liberal" or a "liberal ironist" possibly be?

This question alludes to the challenge of combining both spheres-a combination which is labeled by Rorty as 'metaphysical'. On the more concrete level of (i) to (iii) it is irritating in Rorty's own terms that he is interested in this separation at all because literature's significance consists, according to Rorty, in making us more sensible and accessible to others (cf. PZ, 164; R, 61) even if he characterizes literature as tool of self-creation, thereby restricting its use to oneself [ad (i)]. Understanding ourselves as persons who (re)describe ourselves in new and surprising ways engages

\footnotetext{
22 See I. U. Dalferth on the term 'post-secular': Dalferth (2010).

23 Sometimes, the borders between religion, philosophy and literature break down, for instance, when Rorty characterizes religion itself as a kind of literature or a 'strong poem'; see PC, 32 \& 33.

24 Rorty says ("Philosophy as a transitional genre", in PC, 91 \& 93):
}

[I]ntellectuals of the West have, since the Renaissance, progressed through three stages: they have hoped for redemption first from God, then from philosophy, and now from literature.

As I am using the terms >literature $<$ and $>$ literary culture $<$, a culture which has substituted literature for both religion and philosophy finds redemption neither in a non-cognitive relation to a non-human person nor in a cognitive relation to propositions, but in non-cognitive relations to other human beings, relations mediated by human artifacts such as books and buildings, paintings and songs. These artifacts provide a sense of alternative ways of being human.

25 This is an important semantic shift: 'secularization' is no longer restricted to be only an analytic term but is loaded with an ideological rigor; it is not (only) a description (and could no longer be criticized as not doing justice to the 'facts') but it becomes a slogan. To some extent, however, Rorty sticks to its descriptive meaning and here, unfortunately, he has an oversimplified notion of secularization compounding the traditional view of separating state and church with the decline of religious belief in general. This creates an obstacle for recognizing in which sense we are dealing today with "public religions" (Casanova 1994) or for considering the possibility that secularization itself might be an element in at least the Christian tradition (see Gogarten 1956, Chapter 2). 
us in something that is not merely private but open to dialogue that we won't otherwise engage in without others. In other words, or (re)descriptions come from somewhere else, and to adopt or repudiate these descriptions is an altogether non-private act, shared or 'negotiated' with near or even remote humans [ad (ii)]. The same goes for literature which transcends the sectors in ways that are essential for this means of expression touching our identity by being rooted in communities of individuals [ad (iii)].

However, it is neither clear what is entailed by distinguishing these spheres, nor it is clear which idea of privacy Rorty has in mind. Insofar as it is conceptually impossible to defend a complete inwardness disconnected to something other than itself, a so called 'private' religion has necessarily more than one member. At religion's heart lies an irreducible publicity - a lesson to be learned, for instance, from Wittgenstein's anti-private-language-argument(s) and Taylor's analytic hermeneutics mirrored in the famous phrase on humans as "self-interpreting animals". ${ }^{26}$ For understanding ourselves in surprising new ways we do not have to leave the "cocoon of private selfcreation". ${ }^{27}$ We are already 'outside'. In creating oneself one has left oneself —and religion escalates this very problem for the Rortian dualism of spheres.

\section{Rorty's picture(s) of faith}

Insofar as self-creation belongs to the private sphere and insofar as religion itself is such a self-creative vehicle, according to Rorty's logic, the latter must be doomed to privacy. It is, nonetheless, revealing that Rorty is explicit about restricting religion to the private sector while simultaneously denying religion to be a proper means of self-creation. This suggests a deep tension undergirding Rorty's attitude towards religion. This tension, however, is rooted in several different pictures of what religion is or could mean, none of which mean the same thing. I would like to distinguish three of these contexts in which Rorty locates religious beliefs.

\section{Supranaturalism}

Rorty is not really in touch with the theological literature or philosophical approaches contemplating the possibilities of religious sense. One of the relevant sources of the pragmatist Rorty is the godfather of this line of thinking, William James. Rorty admires James for his philosophical coolness in the sense of cooling down allegedly 'deep' problems to a matter of socially developed questions that we have to deal with accordingly. One prominent example is the notion of truth and its pragmatic reading as usability. Furthermore, Rorty has sympathies with James even when it comes to his characterization of religious faith in the main work The Varieties of Religious Experience from 1902. One reason for Rorty's appreciation might be that James' interpretation locates faith within the individual experience, not in a socially designed network. This leads James to devalue rituals and to criticize the institutional (de)formation

\footnotetext{
26 Taylor (2005, p. 63).

27 Elstain (2003, p. 145).
} 
of faith. What others, like Charles Taylor, take to be problematic, namely, that James was unable to draw connections from faith's 'inwardness' to a visible and practical religious involvement, ${ }^{28}$ Rorty welcomes with open arms because here he meets a real proponent of the descriptive claim that religion is private which would make the call for its restriction superfluous.

There is a tiny problem. Apart from the question of whether James is right in his analysis (of course, he is wrong in more than one regard), he finishes the Varieties by backing up the individual faith by what he calls "over-belief"; in the end, James seems to think that religious belief refers necessarily to some entity beyond space and time - an assumption that is at odds with what James considers usually to be philosophically allowed. By falling back to a supranaturalist framework, James, too much for Rorty's taste, "betrayed his own pragmatism" (SH, 160). Rorty himself seems to think that if this happens even to his hero it will happen to everyone in the subject. Religion without some sort of metaphysical underpinning would lack any sense.

\section{Pragmatism}

Later on, supranaturalist fantasies do not play a significant role in Rorty's critique of religious belief in general and of Christianity in particular (interestingly, Rorty did not participate in the theism-bashing of, for instance, Daniel Dennett and Richard Dawkins). ${ }^{29}$ Perhaps one of the conclusions Rorty was ready to draw from James' confusions had been not to betray his own (neo)pragmatist standpoint — what he would do if he maintained that the religious convictions are 'wrong'. Accordingly, he says farewell to the old question whether there is a God or not. The problem of God's existence is replaced by the pragmatic move concerning the usability of God; we should ask, Rorty says, whether a certain religious tradition incorporates a vocabulary with which we could enrich our picture of ourselves and of our surroundings (cf. PC, 20-21, 24-25). ${ }^{30}$ Or in Robert Brandom's terminology: It is crucial which inferences we can draw from the religious vocabulary and to which divergent responses it leads us. ${ }^{31}$

\section{Religion of love (or: Gianni Vattimo's agape)}

In his last years Rorty got in touch with Gianni Vattimo, an Italian writer and philosopher whose work he appreciated very much. Vattimo has a Catholic background and after having lived in tense distance to the religion of his childhood and youth over decades he regained a sense of the depth of this cosmos. Vattimo himself reports in different works over this important shift that undermines on very different levels Rorty's

\footnotetext{
28 Cf. Taylor (2002, p. 28).

29 See Brümmer (2010).

30 Rorty combines this thesis with the further claim that ontology is to be replaced by cultural politics responsible for integrating or repudiating particular vocabularies against others; cf. PC, 5, 24-25.

31 Rorty mentions also a pragmatic version of theism (see SH, 156) whose participants argue not about whether God exist, but that the thesis of God's theistically conceived existence does the same job as the assumption that tables or quarks exist: in all these cases the existence of pragmatically justified.
} 
thesis of separation. ${ }^{32}$ Vattimo makes his private concern public; perhaps he uses publicity (the publicity of his work and its reception) to understand what he describes in the first place. This operation-to open oneself beyond privacy in order to understand oneself in a self-creative act-is not untypical for a hermeneutical thinker. Furthermore, Vattimo's picture of religious belief is concentrated on finding the appropriate attitude towards a post-secular age — an era that has already faced all sorts of dying or dead faiths. The 'resurrected' faith is, for Vattimo, a kind of obligation: we cannot live today without answering to the Bible, he says (cf. RV, 65). His answer, however, consists in characterizing the Catholic confession as a faith of love-in the Greek sense of agape - as the only rule we need and have (cf. RV, 50).

According to Vattimo, Jesus Christ unmasked the metaphysical tradition which makes him a "weak thinker", someone who said (or: would say) farewell to metaphysical fantasies but without regretting their decline (cf. PC, 33). What we have then is a Christian ethics based on (not founded or justified by) the law of love and the refusal of violence. ${ }^{33}$ There is no power 'behind' that love (that's why Vattimo holds that Christian love is the limit of secularization). This, finally, let him recover the Enlightenment movement once again-but now as enlightened Enlightenment undermining the traditional conflict between faith and reason, which is still defended implicitly by Rorty.

It is obvious that Vattimo's religion of love is hardly to be restricted to a private sector without it being totally destroyed. Rorty finds himself in an uncomfortable situation that is revealing for his whole dualist thinking: on the one hand he has sympathies with Vattimo's Catholicism centered around love; on the other hand its publicity and its necessarily public impact is at odds with Rorty's urgent call for different sectors. ${ }^{34}$

What can we learn from this threefold development? First of all that Rorty met in Vattimo someone who shares some of his most important philosophical values but who has a very different attitude to religion; Vattimo stands for a religion of love as engine for the promotion of solidarity and tolerance, privately and, as such, publically; obviously, the Catholic tradition signifies for Vattimo exactly what Rorty described as the pragmatic turn within our philosophical dealing with religion: namely, that the crucial question is not whether God exists, but whether the 'language of faith' is able to capture one's self-understanding by organizing and deepening it; that is exactly the case with Vattimo. And not falling into the confusion James succumbed to the pragmatist Rorty has to allow for the possibility that the 'language of faith' is actually able to capture and create one's self-understanding; otherwise he, perhaps even more than James, would betray the pragmatist tradition!

Nevertheless, Rorty sticks to his claim; the fact that religion could be part of our self-creation does not, for him, entail that it should be public. As we have seen, this claim is confused since it misses privacy's non-private character. But if we assume for

\footnotetext{
32 Cf. Vattimo (1999, p. 71).

33 The content is mirrored in the style because Vattimo presents his book Belief as an "upbuilding discourse" (ibid., p. 110 — a reference to Kierkegaard).

34 Interestingly, Rorty restricts here his critique of Christianity to the institution that represents it. Therefore, the call for separation refers only to coming to terms with the church as institution which deescalates the problem to (just) a legal matter; cf. RV, 41.
} 
a moment that this pitfall did not exist, we run into another problem: Rorty's hidden Cartesianism! Apparently, Rorty was not fully aware of the fact that he reactivated a picture of the self he was constantly and eagerly critical of: an autonomous agent securing himself isolated from his surroundings. It is difficult to see how to appreciate the Nietzschean legacy (if Rorty's 'separationism' is actually in Nietzsche's sense-what I doubt) without standing with one leg precisely in the dualist tradition to which Rorty said goodbye more than once. How do create both selves one identity? How does the private self interact with his public brother? And where? (Perhaps in the epiphysis as Descartes might have suggested?) The institution of privacy remains ambivalent-or metaphorically speaking: Rorty cannot keep the igloo cold enough in order to avoid the melting point.

\section{To conclude: irony without irony?}

We have now all ingredients together to deal constructively with Rorty's claim: If self-creation is necessarily a publically shared act insofar as my self-picture is not independent from the view of others, if religious belief is such a self-creation or contributes to it in certain ways, if this self-creative understanding should be ironic in the sense of playing seriously with different vocabularies, if this ironic game widens our moral sense in deepening our ability to accept the non-relative contingency of our own hopes, desires, expectations and commitments, if this moral sense effects the public virtue of tolerance and solidarity by an ethics of love-if all this is true, and it is true according to Rorty, then religion belongs essentially to the public sphere because it donates new possibilities as surprising, unexpected and interesting descriptions that irritate, correct, deepen - as possibilities — what we take to be reality. ${ }^{35}$

In order to recognize this you have to be a real ironist - " "the sort of person who faces up to the contingency of his or her own most central beliefs and desires-someone sufficiently historicist and nominalist to have abandoned the idea that those central beliefs and desires refer back to something beyond the reach of time and chance." We should use Rorty as an author who showed us what irony could come to-in the positive sense of an ironic tolerance and openness as well as in the problematic sense of an irony without irony. ${ }^{36} \mathrm{~A}$ 'public religion' that deserves its name might help us to complete Rorty's lesson by teaching us to be "the sort of person" who we are not yet, but will hopefully some day become: a self-ironic animal who sometimes sit under the pulpit and may even sometimes stand on it!

\footnotetext{
35 What Rorty presents as the eminent force of and the need to new self-descriptions is prominently fulfilled in religion as a collection of language-events. Of course, it would be necessary to work out in more detail this approach that has its sources in what has been called "hermeneutical theology" (including authors like Ernst Fuchs, Gerhard Ebeling and Eberhard Jüngel)—but this is the work for another paper, hopefully a book.

36 See for the notion of a negative irony: Reece (2002, esp. chapter 6: "From the Metaphysical to the Ordinary").
} 


\section{References}

Amesbury, R. (2008). Religious neutrality and the secular state: The politics of God's absence? In I. U. Dalferth (Ed.), The presence and absence of God. Tübingen: Mohr Siebeck.

Brümmer, V. (2010). Dawkins' religion. Neue Zeitschrift für Systematische Theologie und Religionsphilosophie, 52, 2.

Casanova, J. (1994). Public religions and the modern world. Chicago: The University of Chicago Press.

Conant, J. (2000). Freedom, cruelty, and truth: Rorty versus Orwell. In R. Brandom (Ed.), Rorty and his critics. Oxford/Malden, MA: Oxford University Press.

Dalferth, I. U. (2010). Post-secular society: Christianity and the dialectics of the secular. Journal of the American Academy of Religion, 78(2), 1-29.

Elstain, J. B. (2003). Don't be cruel: Reflexions on Rortyan liberalism. In C. Guignon \& D. R. Hiley (Eds.), Richard Rorty (Contemporary Philosophy in Focus). Cambridge/New York: Cambridge University Press.

Gogarten, F. (1956). Der Mensch zwischen Gott und Welt. Stuttgart: Vorwerk.

Habermas, J. (2005a). Religion in der Öffentlichkeit. Kognitive Voraussetzungen für den ,öffentlichen Vernunftgebrauch' religiöser und säkularer Bürger. In idem, Zwischen Naturalismus und Religion. Philosophische Aufsätze. Frankfurt a.M.: Suhrkamp.

Habermas, J. (2005b). Die Grenze zwischen Glauben und Wissen. Zur Wirkungsgeschichte und aktuellen Bedeutung von Kants Religionsphilosophie. In idem, Zwischen Naturalismus und Religion. Philosophische Aufsätze. Frankfurt a.M.: Suhrkamp.

Hegel, G. W. F. (1955). In J. Hoffmeister (Ed.), Die Vernunft in der Geschichte (5th ed.). Hamburg: Meiner.

Heidegger, M. (1959). Unterwegs zur Sprache (14th ed.). Stuttgart: Klett-Cotta.

Reece, G. L. (2002). Irony and religious belief. Tübingen: Mohr Siebeck.

Rorty, R. (1979). Philosophy and the Mirror of Nature (PMN). Princeton: Princeton University Press.

Rorty, R. (1989). Contingency, Irony, and Solidarity (CIS). Cambridge: Cambridge University Press.

Rorty, R. (1997). Truth, politics and 'post-modernism' (TP). Spinoza lectures. Amsterdam: Van Gorcum.

Rorty, R. (1999). Philosophy and Social Hope (SH). London: Pinguin Books.

Rorty, R. (2001). Philosophie \& die Zukunft. Essays (PZ) (2nd ed.). Frankfurt a.M.: Fischer (original German edition).

Rorty, R. (2003a). Religion in the Public Square: A reconsideration (PS). Journal of Religious Ethics, 31(1), 141-149.

Rorty, R. (2003b). Der Roman als Mittel zur Erlösung aus der Selbstbezogenheit (R). In J. Küpper \& C. Menke (Eds.), Dimensionen ästhetischer Erfahrung (pp. 49-66). Frankfurt a.M.: Suhrkamp (original German article).

Rorty, R. (2007). Philosophy as Cultural Politics (PC). Philosophical papers IV. Cambridge: Cambridge University Press.

Rorty, R. \& Vattimo, G. (2005). The Future of Religion (RV) (S. Zabala, Ed.). New York: Columbia University Press.

Rössler, B. (2007). Der Wert des Privaten. Frankfurt a.M: Suhrkamp.

Schapp, W. (1953). In Geschichten verstrickt. Zum Sein von Mensch und Ding (4th ed.). Frankfurt a.M: Vittorio Klostermann.

Taylor, C. (2002). Varieties of religion today. William James revisited. Cambridge, MA: Harvard University Press.

Taylor, C. (2005). Self-interpreting animals [1985]. In Human agency and language. Philosophical papers 1. Cambridge: Cambridge University Press.

Tillich, P. (1975). Die religiöse Substanz der Kultur. In Schriften zur Theologie der Kultur (Gesammelte Werke, ed. by R. Albrecht, Bd. IX) (2nd ed.). Stuttgart: Kreuz Verlag.

Vattimo, G. (1999). Belief. Cambridge: Cambridge University Press. 